\title{
Inter-structural Space Effect of Fanya juu and Soil Bund Soil and Water Conservation Structures on Selected Soil Properties: In the Case of Habru District, North Ethiopia
}

\author{
Muluneh Bogale ${ }^{1^{*}}$ Alemayehu Regassa ${ }^{2}$ Amsalu Tilahun ${ }^{3}$ \\ 1.Department of Natural Resource Management, Debark University College of Agriculture and Environmental \\ Science (DKU CAES), P.O Box 90, Debark, Ethiopia \\ 2.Department of Natural Resource Management, Jimma University College of Agriculture and Veterinary \\ Medicine (JUCAVM), P.O Box 307, Jimma, Ethiopia
}

\begin{abstract}
Land degradation is one of the most serious environmental problems in Ethiopia. To halt the problem, large scale soil and water conservation (SWC) practices such as; fanya juu, soil bund and other physical structures were implemented in the different parts of the country including Habru district. However, development of fertility gradient between the two successive SWC structures makes debatable to use the implemented structures in the sustainable manner. The study aimed at evaluating the spatial variability in soil properties between inter-structuralterrace area. Representative Kutaye catchment was deliberately selected based on the availability of fanya juu and soil bund. Then the catchment was sub-divided into two sub-watersheds, cropland treated with fanya juu and cropland treated with soil bund based on the structural dominance. Inter-structure-terrace plots were independently selected and systematically replicated (second, fourth and sixth) between two SWC structures for the purpose of soil sampling. In order to evaluate selected soil property variation, the soil samples were taken following the contour between the two successive structures. Additionally, undisturbed core samples were collected for the bulk density analysis. The samples were analyzed following standard laboratory procedure and parameters like; soil texture, bulk density $(\mathrm{Bd})$, soil reaction $(\mathrm{pH})$, organic carbon $(\mathrm{OC})$, total nitrogen $(\mathrm{TotN})$ available phosphorus $(A v P)$, cation exchange capacity (CEC), exchangeable potassium $(\mathrm{K}+)$ and electrical conductivity (EC) were determined. Statistical analysis was performed using SPSS v.20 software. Parameter relative distance was created for allowing comparison; because the distance between the successive SWC structures were highly variable. Oneway ANOVA was used; selected soil properties as dependent and relative distance (inter-structure area) as independent variables. Tukey (HSD test) was used for mean separation between relative distance at $p<0.05$. The result revealed that soil properties percentage of sand and clay significantly influenced by inter-structure-spaces plots treated with fanya juu at $p<0.05$. In both SWC structures, cation exchange capacity (CEC), exchangeable potassium $(\mathrm{K}+)$ and bulk density $(\mathrm{Bd})$ were significantly $(\mathrm{p}<0.05)$ affected with inter-structure space. In order to manage variation in some soil properties between the successive SWC inter-structures-space area; optimizing its' inter-structural terrace space and application of site-specific soil management practices were suggested with appropriate contour ploughing.
\end{abstract}

Keywords: Fanya juu, Inter-structural space, Land degradation, Soil bund, Soil property, Soil and water conservation, Soil and Water Conservation practices

DOI: $10.7176 / \mathrm{JEES} / 10-3-01$

Publication date:March $31^{\text {st }} 2020$

\section{INTRODUCTION}

Land degradation in the form of soil erosion, depletion of surface and ground water and loss of biodiversity are among the principal global environmental problems that are an obstacle for development and food security prospect (Kessler et al., 2008; Shiene, 2012). Some forms are the result of interaction of normal natural processes of physical shaping of the landscape and high intensity of rainfall. But with the increase in human interaction with nature due to high population, the extent and scale of the problem has been dramatically increased (Tadele et al., 2011). Among the forms of land degradation, severity of soil degradation is most common and curtail in SubSaharan African countries. Occurrence of severely degraded soils is very high. Out of 350 million hectares of the total land area of the region 100 million hectares were estimated to be severely degraded (Zingore et al., 2015).

Ethiopia is one of the most well-endowed countries in Sub-Saharan African (SSA) in terms of natural resource potential. However, the highlands with an altitude of over 1500 meter above sea level (m.a.s.l), having inherently good soils and relative abundant rainfall areas'; that account for more than $43 \%$ of the country, $95 \%$ of the cultivated area, $75 \%$ of the livestock and host about $88 \%$ of the population have been victim of soil degradation for a long period of time (Berhanu and Swinton, 2003; Alemayehu et al., 2006). FAO (1986) on Ethiopian highland reclamation study (EHRS) estimated that, annually over 1.9 billion tons of soils were lost from the highlands and about half of the land area (27 million hectares) and over one-fourth (14 million hectares) significantly and seriously eroded respectively (Tadele et al., 2011). This leads to the widespread phenomenon for the loss of arable 
lands, particularly for the northern Ethiopia (Lakew et al., 2006; Assemu and Shigdaf, 2014).

In an attempt to address the problem over the past ten years, Amsalu and Graaff (2007) reported that, the government initiated soil and water conservation (SWC) work and extensively introduced through food for work (FFW) payment. Despite, sustainable utilizations were not expected and the success has been uncertain and limited. In many parts of the northern highlands various soil and water conservation (SWC) programs have been unsuccessful (Badege, 2001). Because of the emphasis has been on the construction of physical SWC measures through peasant associations (PAs) and the conservation activities applied through blanket recommendation principle and top-down approach (Bewket, 2001; Bewket and Sterk, 2002; Bewket, 2007). Blanket approach to conservation intervention could make the measures inconvenient to local conditions and eventually reduce their acceptance level by technology users (Amsalu and Graaff, 2007). Esser et al. (2002); Bewket (2007) also criticized that, the users were eventually considered as ignorant of land management and were not allowed to comment on the introduced conservation measures.

In the new paradigm, the government recognized past experience and developed mechanisms to mobilize the farmers with the actors of local extension and development team (DT) in terms of participatory campaign based soil and water conservation (SWC) work for large scale watershed management. The program was aimed at doubling agricultural productivity by strengthening natural resource conservation (MOFED, 2010). At the moment farmers were committed and voluntarily spent on average 40 to 50 days working on the programs (MOFED, 2013). More than 15 million people participated without any incentives and annually over 3000 community watersheds were treated with biological and physical soil and water conservation (SWC) measures (Dessalegn et al., 2015). Similarly, in the Habru district large scale soil and water conservation (SWC) structures (soil bund, fanya juu and other physical structural measures) were implemented at different spacing intervals. But during rainy season and tillage practice, there is materials transportation from the upper embankments and redistribution towards the lower embankment between the successive structures. Soil and water conservation (SWC) structures promotes erosion and deposition and cause for the existence of soil nutrient movement dynamics (fertility gradient) and physical movement of the soil particles in the field. Therefore, the purpose of the study was to evaluate the spatial variability in soil properties between the successive SWC structures or assess the effect of fanya juu and soil bund interstructural space on selected soil properties variation.

\section{MATERIALS AND METHODS}

\subsection{Description of the Study Area}

Location: The study was conducted in Kutaye catchment located in Habru district, which is among the most important place where SWC practices implemented in the North Wollo zone, Amhara regional state of Ethiopia. It located at about 490 and 30 kilometers north of Addis Ababa and south of Woldiya respectively. It covers 47210 hectares. Geographically situated at an altitude ranging from 1430-2800 meters above sea level (m.a.s.1) and locate between latitude of $11^{\circ} 31^{\prime} 33.0^{\prime \prime}$ to $11^{\circ} 47^{\prime} 32.35^{\prime \prime} \mathrm{N}$ and longitude $39^{\circ} 33^{\prime} 05.52^{\prime \prime}$ to $40^{\circ} 20^{\prime} 06.31^{\prime \prime} \mathrm{E}$. The topography nature of the area is characterized $40 \%$ relatively level, $35 \%$ mountains, $22 \%$ valley and $3 \%$ other landscape situation (HWRDAOR, 2012). The dominant part is rugged topography that consists of very high mountains, deeply incised canyons and gorges, valleys and plateaus (NTNU, 2002).

Population: The district has an estimated total population of 192742 out of which 21600 are settled in the urban areas and 171142 in the rural (CSA, 2007). The patterns of population distribution are expressed as $3.5 \%$ in the highland, $40 \%$ in the intermediate and $56.5 \%$ in lowland agro-climatic region of the area (HWRDAOR, 2012).

Geology and soil: The major soils are Leptosols, Cambisols, Vertisols, Andosols and Luvisols. Leptosols are the dominant soil types followed by Cambisols, Vertisols, Andosols and Luvisols. Leptosols are shallow, mostly brown or yellowish brown (FAO, 1986).

Like other districts in Amhara regional state, the most dominant geological formation in the area is Tertiary volcanic rock such as; Ashangi formation, Aiba formation and Aljae formation (FSC and DPO, 2011). However, the existence of Cenozoic volcanic rocks with some sedimentary rocks is very high. The Cenozoic volcanic rocks have developed from tertiary flood basalt sequences with intercalation of felsic lava and pyroclastic rocks up to three km thick (FAO, 1986). 


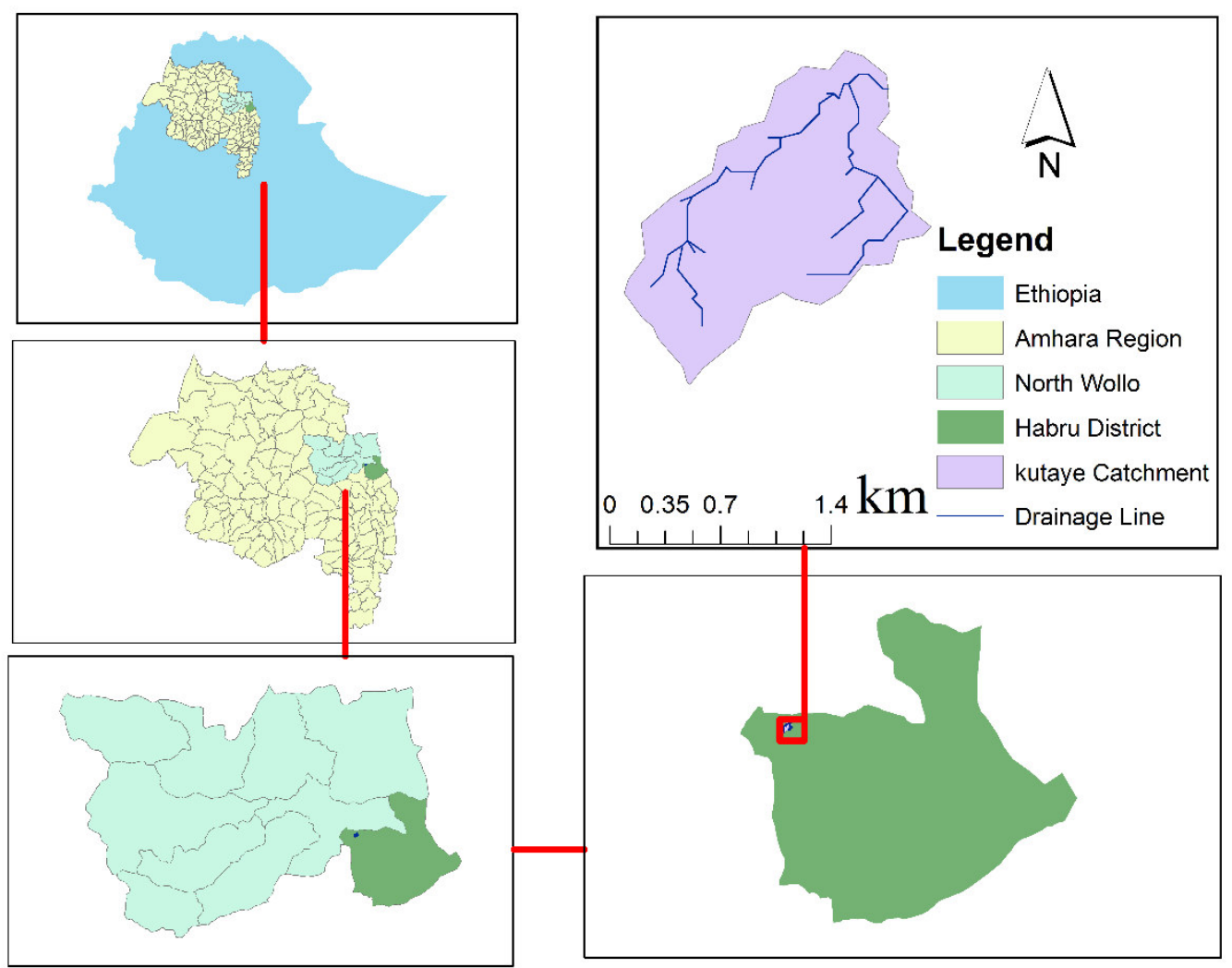

Figure 1: Location map of the study area in the Habru district of Ethiopia.

Climate: the district is characterized by three agro-climatic zone: Dega (high land), Woynadega (intermediate zone), and Kola (low land). The mean annual maximum and minimum temperatures is $28.6{ }^{\circ} \mathrm{C}$ and $15{ }^{\circ} \mathrm{C}$, respectively whereas the mean annual rainfall of the district varied between 750 and 1000 millimeters (HWRDAOR, 2012). The main rainy season is from mid of June to end of September and the hottest months are from March up to the mid of June. The coldest months are October up to January. The lowland parts of the area are mostly dry in certain months due to the intermittent nature of the rainfall and erratic condition (Lakew et al., 2006).

Vegetation cover: The vegetation cover has been removed and replaced by cultivation fields, grazing land and plantation of exotic species such as eucalyptus species. The vegetation pattern is mostly dominantly manmade plantation with eucalyptus plantation around farm boundaries, homesteads and home gates while, the natural vegetation is almost being removed. Based on HWRDAOR (2012) report from a total area of 1614 hectare of forest resource 772 hectare $(47.83 \%)$ and 842 hectares $(52.16 \%)$ are occupied by natural forest and manmade plantation respectively. Remnants of the indigenous vegetation such as Juniperus Procera, Podocurpus falcatus, Olea Africana, at the highland part and other indigenous shrub species are found scattered here and there. Acacia is dominant shrub in the low land parts of the district (Shiene, 2012).

Agriculture and farming system: The major farming system of Habru district is mixed cereal-livestock because of the small average farm size is which 0.5 hectares. Among the annual crops, teff, sorghum, wheat and barley are dominant, accounting for $25 \%, 18 \%, 16 \%$ and $11 \%$ of the total, respectively and rice, maize and oats are also partially grown. Chickpea, pea. vetch and field bean are the major legume crops accounting for $16 \%$ of the total crop production (HWRDAOR, 2012). Farmers rotate cereals with legumes to maintain soil fertility and crop yield. Farmers use traditional tillage implement known as 'Maresha' an ox-drawn plough for the preparation of the land for certain crops, which has been used for more than two thousand years (Tilahun et al., 2001). Traditional retillage practices, known as Shilshalo, are usually performed about six weeks after maize and sorghum sowing. Shilshalo has various purposes such as harrowing, which improve soil air, water and nutrient circulation, root development, and uproots and kills weed and optimizes plant density. The traditional up and down cultivation of the land practiced for centuries has leads to severe soil erosion and land degradation (Shiene, 2012).

Soil and water conservation (SWC): In order to mitigate the land degradation problem and improve the productive capacity of the land thereby community livelihood, SWC practices were introduced since three decades. The SWC technologies (commonly called physical structures) have been mostly practiced in the degraded watershed with the support of safety net program through food for work and free mobilization of the community. Soil and water conservation (SWC) structures like soil bund, fanya juu, stone faced soil bund, micro-basin, farm 
ponds, hillside terrace, cheek dams were practiced in the study area. Also, some forage plants species had usually planted for the stabilization of the structures.

\subsection{Sampling}

From the list of watersheds in the Habru District, Kutaye catchment which covers 1680.5 hectares was purposively selected based on the availability of soil bund and fanya juu treatment measures in the field. A general visual field survey of the area was made to have a general overview of the variations in the study area and selecting appropriate sites for soil sampling. Then the study watershed was sub-divided into two sub-watersheds. Inter-structures cropland with fanya juus were selected in one sub-watershed, whereas inter-structures cropland with soil bunds were selected from another sub-watershed of the catchment based on the structural dominance (Kebede et al., 2011). All of inter-structure croplands have been under the same cropping history, farm management and the same age long of SWC; both have been installed since 2012. The number of inter-structure plots per treated croplands were (greater or equals to 7 with minimum and maximum distance or interval of 4 to $10 \mathrm{~m}$ between two successive SWC structures).

Sampling plots in each fanya juu and soil bund structures were selected and systematically replicated three times; second, fourth and sixth inter-structure plot area between the two successive structures independently. From each sampling plot, five mixed soil samples were taken on a transect between two bunds (between the upper and the lower bunds) along the slope following the contour (figure 2) for laboratory analysis. The first and the last samples were taken at $1.5 \mathrm{~m}$ distance from the lower (deposition) and $1.5 \mathrm{~m}$ away from the top of the structures following (Vancampenhout et al., 2006). The other three soil samples were collected at equidistance (at the shoulder, at the center and at the foot) between two successive structures. A total of 30 composite soil samples 2 (types of SWC structures) $\times 5$ sampling distance $(1.5$ meter from the deposition, $1.5 \mathrm{~m}$ from the upper structure, equidistance ("at the center, from the center to the lower structure and from the center to the upper structure") $\times 3$ inter-structure areas were collected using an auger. All of the soil samples were taken at a depth of up to $20 \mathrm{~cm}$. Parallelly, the soil core samples; undisturbed soils were collected for the determination of soil bulk density.

In reference to the non-conserved land or areas where no SWC measures were applied (control plot) adjacent to the watershed, because of unavailability of non-conserved (non-terraced) plot, the central parts of the successive structures were the best resemble (Dercon et al., 2003). After all, for the purpose of easy of handling and storage, reduction of sample size was made by quartering (Bashour and Sayegh, 2007). The collected soil samples were put in a labeled plastic bag. Finally, an analysis was made in Sirinka soil laboratory of Amhara Regional Agricultural Research Institute (ARARI).

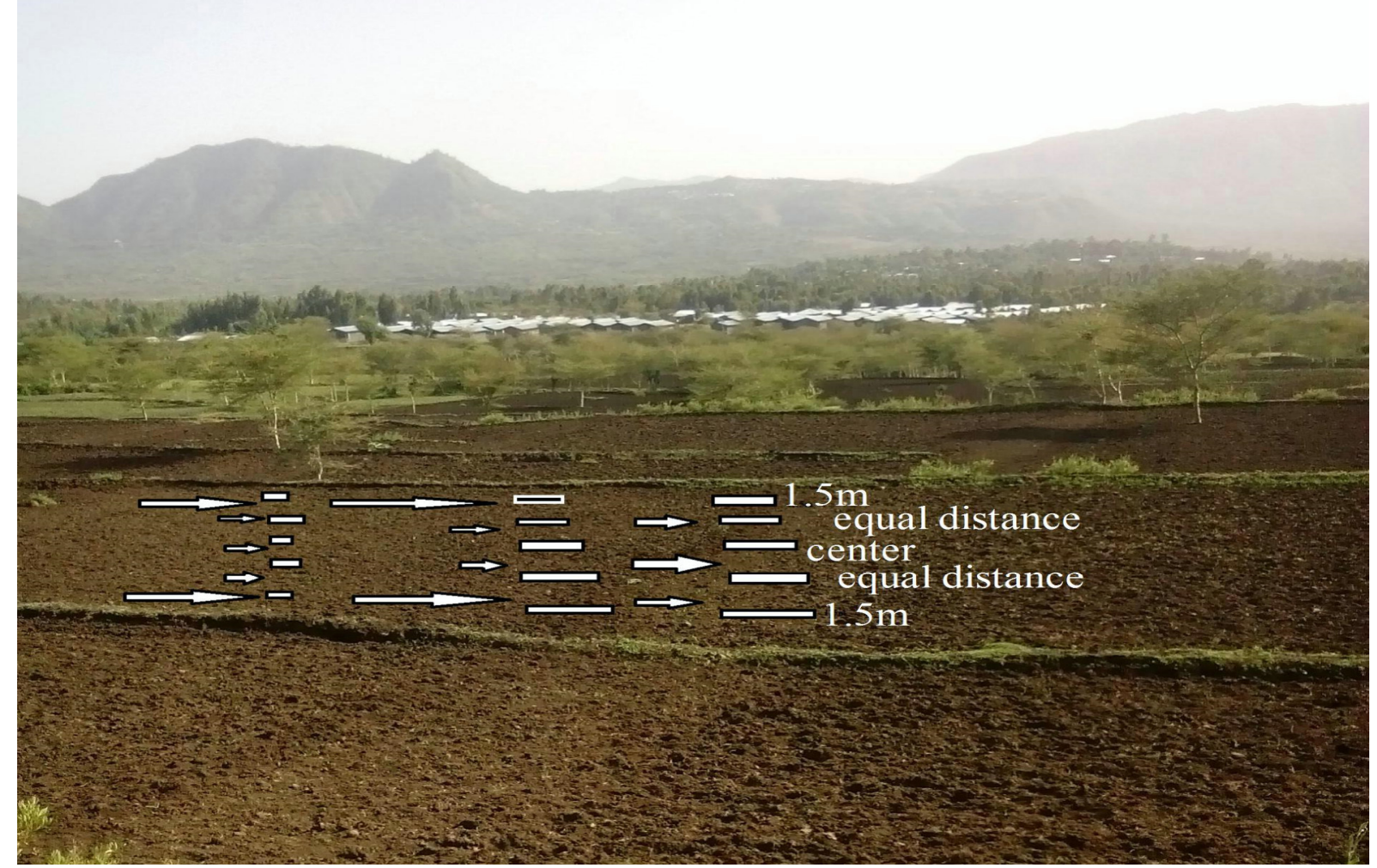

Figure 2: Soil sampling interval between inter-structure spaces of soil bund and fanya juu SWC structures 


\subsection{Soil Analysis}

After all the soil samples were air-dried, crushed and passed through a $2 \mathrm{~mm}$ sieve and preserve for the determination of physical and chemical property analysis. Parameters like soil texture and bulk density $\left(\mathrm{Bd} \mathrm{gmcm}^{-}\right.$ ${ }^{3}$ ) and soil reaction $(\mathrm{pH})$, organic carbon $(\mathrm{OC} \%)$, total nitrogen ( $\mathrm{TN} \%$ ), available phosphorus $(\mathrm{AvP} \mathrm{mg} / \mathrm{kg})$, exchangeable potassium $\left(\mathrm{K}^{+} \mathrm{cmol} / \mathrm{kg}\right)$, cation exchange capacity $(\mathrm{CEC} \mathrm{cmol} / \mathrm{kg})$ and electrical conductivity $(\mathrm{EC}$ $\mathrm{S} / \mathrm{m})$ were determined.

The particle size distribution of each proportion of sand, silt and clay were determined using standard hydrometer methods provided by (Kettler et al., 2001). Hydrogen peroxide $\left(\mathrm{H}_{2} \mathrm{O}_{2}\right)$ was used to destroy organic matter while, sodium hex metaphosphate $\left(\mathrm{NaPO}_{3}\right)_{6}$ and sodium carbonate $\left(\mathrm{Na}_{2} \mathrm{CO}_{3}\right)$ were used as dispersing agent. The bulk density of the soil also estimated from the oven dry mass of soil in the core sampler and volume of undisturbed soil cores by using a core sample method after the soil was dry in oven for $105{ }^{\circ} \mathrm{C}$ for 24 hours (Bashour and Sayegh, 2007).

The organic carbon content was determined using the Walkley-Black oxidation wet digestion and titration method (SERA-IEG, 1995). A sample of air- dried soil were transferred into a $100 \mathrm{ml}$ plastic beaker and $50 \mathrm{ml}$ of distilled water added. The suspension of 1:2.5 (soil to water on a mass to volume ratio) had shaken for 10 minutes on a reciprocal shaker and left to stand for 30 minutes. The mixture had been stirred again for 2 minutes and the $\mathrm{pH}\left(\mathrm{pH}-\mathrm{H}_{2} \mathrm{O}\right)$ of the suspension was read using a $\mathrm{pH}$ meter (Justin et al., 2012). Total nitrogen was determined by the macro-Kjeldahl digestion-distillation and titration method following Jackson (1958), available phosphorus (AvP) was determined using Olsen's extraction method developed by Olsen (1965) and exchangeable potassium $(\mathrm{K}+)$ also measured by atomic absorption spectrophotometer (Black, 1965). The cation exchange capacity (CEC) was determined by extraction with ammonium acetate (Chapman, 1965). The electrical conductivity of the soil was determined by EC-meter.

\subsection{Statistical Analysis}

To evaluate the spatial variability of selected soil properties between the successive SWC structures or soil property variation between inter-structure spaces, statistical test was performed by using Statistical Package for Social Sciences (SPSS) v.20.0. Creation of parameter relative distance was necessary for allowing a comparison of spatial variability among inter-structural terrace space of the conservation structures. Because the distance between the successive structures were highly variable, the variation ranged from $4 \mathrm{~m}$ to $10 \mathrm{~m}$. The relative distance:

$$
\text { Dr }=\frac{\mathbf{L i}}{\mathbf{L}}
$$

where Dr: Is the relative distance dimensionless; Li: The slope position at sampling site $\mathbf{i}$ : With the upper part of the terrace as reference $(\mathrm{m})$, and $\mathbf{L}$ : The total length between the successive SWC structures (m). The minimum and maximum average value of the distance of one structure to the next goes towards 1 and 0 , respectively and since the rest of the sample taken as equal distance, then the relative distances on each plot were as follows: $0.00 \mathrm{~m}$ (deposition), $0.25,0.50,0.75$ and 1.00 meters (upper sample) as, developed by Dercon et al. (2003).

To evaluate the effect of inter-structure space of soil and water conservation (SWC) structures on selected soil properties; soil physical and chemical properties were subjected to one way-analysis of variance (ANOVA) at 95\% significance level following general linear model (GLM). Inter-structural space (relative distance) considered factor variables and the selected soil properties were the dependent variables. Additionally, Karl person's correlation was made in predicting the relationship between selected soil properties.

\section{RESULTS AND DISCUSSION}

\subsection{Spatial Variability of Selected Soil Physical Properties in SWC Inter-structure Area 3.1.1. Soil Texture}

According to FAO (2000), the particle size distribution of the soil influences the movement and availability of soil moisture, aeration, nutrient and the resistance of the soil to root penetration. Also, it affects the physical properties related to the soil's susceptibility to degradation and governing aggregate stability of the soil structure.

Analysis of variance (Table 2) deduces that, there was a significant difference between relative distance in relation to clay and sand contents of the soil texture in fanya juu SWC of the successive structures. But there was no significant different under plots which treated with soil bund conservation structures. Consequently, in related to the percentage of silt content, no significant different between relative distance in both of the conservation structures at $\mathrm{p}<0.05$.

In mean comparison (Table 1), there was a significant different between 0.00 and $0.25,0.750 .75$ and 1.00 meter relative distances in clay percentage plots treated with fanya juu conservation structures but no significant variations were observed under soil bund. Significantly higher mean value of clay at 0.00 -meter relative distance was detected under fanya juu at $\mathrm{p}<0.05$. In the same fashion in relation to the proportion of sand content significant variation was observed between the mean effect of each pair of relative distance. Between the upper and lower 
zones (relative distance) differences were observed. However, the variation was not significant between $(0.25 \mathrm{~m}$ and $0.50 \mathrm{~m}$ ). In the case of soil bund, the particle size distribution of the sampled soils was not significantly influenced by relative distance. The highest clay content $(62.68 \%$ and $48.33 \%)$ were recorded at the lower relative distance of fanya juu and soil bund SWC structures respectively without consideration of the significant variation in soil bund and gradually lower when the relative distance goes to erosional zones (towards the upper position or $1.00 \mathrm{~m}$ relative distance). The inverse process was exhibited in the case of sand content in the study catchment. The highest proportion of clay content in the lower relative distance $0.00 \mathrm{~m}$ (deposition) probably; tillage operation and water erosion cause fine materials to be transported and deposited in the lower part of the field, while the soil profiles were cutting off the top $1.00 \mathrm{~m}$ relative distances (the upper part) of inter-structure terraced site.

In the case of soil bund, the case might be the presence of ditch which prevent fine materials from being washed out by runoff and remain in the field. Whereas, plots treated with fanya juu, the significantly higher value of clay can be justified as, fanya juu conservation structures were two-sided receivers of finer particles as well as other soil materials: first, soils trucked from the upper field were deposited near to the embankment; second, construction of fanya juu by itself digging ditches and heaping the soil on the upper sides to form the bunds. This attribute finer particles left and coarse fragments were sliding back. According to Hamidreza et al. (2017), the gravitational force tending splash particles to move downslope; more effects of raindrops mass in downslope direction and finally the lower size soil particle splash in downslope position. Through time those materials deposited at the lowest point of the terrace and accumulated.

Table 1: Effect of fanya juu and soil bund inter-structure space (m) on selected soil physical properties in Kutaye catchment

\begin{tabular}{lllllllll}
\hline \multirow{2}{*}{$\begin{array}{l}\text { Relative distance } \\
(\mathrm{m})\end{array}$} & \multicolumn{3}{c}{ Soil bund SWC } \\
\cline { 2 - 9 } & Clay\% & Silt\% & Sand \% & $\begin{array}{c}\text { Bd } \\
\text { gcm-3 }\end{array}$ & Clay \% & Silt \% & Sand \% & $\begin{array}{c}\text { Bd } \\
\text { gcm-3 }\end{array}$ \\
\hline Lower 0.0 & $48.33 \mathrm{a}$ & $25.08 \mathrm{a}$ & $26.58 \mathrm{a}$ & $1.200 \mathrm{a}$ & $62.68 \mathrm{a}$ & $21.90 \mathrm{a}$ & $15.42 \mathrm{a}$ & $1.20 \mathrm{a}$ \\
0.25 & $48.17 \mathrm{a}$ & $25.00 \mathrm{a}$ & $26.83 \mathrm{a}$ & $1.20 \mathrm{a}$ & $52.92 \mathrm{ab}$ & $28.52 \mathrm{a}$ & $18.56 \mathrm{ab}$ & $1.27 \mathrm{ab}$ \\
0.50 (control) & $47.92 \mathrm{a}$ & $25.17 \mathrm{a}$ & $26.92 \mathrm{a}$ & $1.33 \mathrm{a}$ & $51.88 \mathrm{~b}$ & $28.98 \mathrm{a}$ & $19.13 \mathrm{ab}$ & $1.27 \mathrm{ab}$ \\
0.75 & $48.17 \mathrm{a}$ & $24.92 \mathrm{a}$ & $27.17 \mathrm{a}$ & $1.47 \mathrm{a}$ & $45.33 \mathrm{~b}$ & $27.50 \mathrm{a}$ & $27.16 \mathrm{bc}$ & $1.33 \mathrm{ab}$ \\
Upper 1.00 & $47.75 \mathrm{a}$ & $23.75 \mathrm{a}$ & $28.50 \mathrm{a}$ & $1.53 \mathrm{~b}$ & $44.10 \mathrm{~b}$ & $23.98 \mathrm{a}$ & $31.92 \mathrm{c}$ & $1.53 \mathrm{~b}$ \\
\hline SEM $( \pm)$ & 0.29 & 0.58 & 0.67 & 0.10 & 3.16 & 3.45 & 2.76 & 0.08 \\
p-value & 0.310 & 0.170 & 0.120 & $0.027 *$ & $0.001 *$ & 0.246 & $0.001^{*}$ & $0.023^{*}$ \\
\hline
\end{tabular}

Columns having the same letters are not statistically significant at 0.05 significant level; $\mathrm{Bd}=\mathrm{Bulk}$ density of the soil; $\mathrm{p}=$ probability and SEM $=$ Standard Error mean

In the opposite sand fragment and course materials left at the highest position of the structures. The results of this investigation are in agreement with that of Herweg and Ludi (1999) who stated that, the removal of topsoil at the loss zone (highest slope position) causes the subsoil potentially rich in clay material to move down slope and scatter on the top of the fertile accumulation at lower position of the inter-structure terrace area. Million (2003) also reported higher clay content at the lower slope position of the inter-terrace area, where severe erosions were pronounced to occur, regardless of the original ground slope and width of treatments considered. Worku et al. (2012) also pointed out the existence of higher clay fraction in the lower inter-structure slope gradient due to the case of depositions from the upper side.

\subsubsection{Bulk Density of the Soil}

In both SWC structures, the bulk density of the soil significantly influenced by inter-structural space (Table 2). Significantly higher mean bulk density value $\left(1.53 \mathrm{~g} / \mathrm{cm}^{3}\right)$ was investigated at $1.00 \mathrm{~m}$ relative distance (upper part) in both SWC structures as compared to other relative distances. The value at erosional zone $(1.00 \mathrm{~m})$ increased by $27.50 \%$ as compared to that of depositional zone $(0.00 \mathrm{~m})$. An overall decreasing trend in soil bulk density value from the upper position to the lower was observed (Table 1).

The possible explanation might be clearing away of the organic matter from the upper slope position (relative distance) and accumulated near the lower relative distance. In the opposite, exposition of sub-soil to the surface in the upper position and increase in rock fragment leads to higher bulk density. Herweg and Ludi (1999) also reported that, the complete removal of topsoil at the soil loss zone causes the subsoil dominated by clay and organic materials while moving down slope and were put on the lower accumulation zone. Additionally, during construction and maintenance oppression of SWC structures, some rock martials to move easily to the back sides of the structure around $1.00 \mathrm{~m}$ relative distances. While in the lowest depositional zone most organic materials were concentrated leads to positive improvement of the soil pore space condition as well as aggregate stability and compaction reduction. Increasing the organic fraction resulted in decreasing of the total weight and bulk density of the soil. The study was consistent with the finding of Lindstrom (2001), decrease in bulk density of cultivated soils in lower than in the upper side gradient associated with the corresponding decline in soil organic matter content with respected to increase in slope gradient. Worku et al. (2012); Birhanu and Assefa (2017), also explained that, the value of soil bulk density was higher at the upper gradient with corresponding decline in soil 
organic carbon. According to Gupta (2004) bulk densities of the soil was inversely related to the amount of pore space and soil organic materials.

Additionally, the pareason product movement correlation coefficient (Table 4) also showed, there was a negative relationship between bulk density and organic matter $(\mathrm{r}=0.193)$. Bulk density was also negatively and significant $\left(\mathrm{r}=-0.620^{* *}\right)$ correlated with clay content. It also positively and significantly $\left(\mathrm{r}=0.755^{* *}\right)$ related with sand proportion.

Table 2: Mean square (MS) of between groups and estimates for one-way analysis of variance of soil chemical and physical properties under Fanya juu and Soil bund SWC inter-structure space in Kutaye catchment.

\begin{tabular}{|c|c|c|c|c|c|c|}
\hline \multirow{3}{*}{$\begin{array}{l}\text { Selected } \\
\text { soil } \\
\text { properties }\end{array}$} & \multicolumn{6}{|c|}{ Relative distance } \\
\hline & \multicolumn{3}{|c|}{ Fanya juu SWC structures } & \multicolumn{3}{|c|}{ Soil bund SWC structures } \\
\hline & MS & F-ratio & p-value & MS & F-ratio & p-value \\
\hline Clay & 164.955 & 11.036 & $0.001 *$ & 220.471 & 1.793 & $0.310 \mathrm{Ns}$ \\
\hline Silt & 28.677 & 1.611 & $0.246 \mathrm{Ns}$ & 40.208 & 1.287 & $0.170 \mathrm{Ns}$ \\
\hline Sand & 140.598 & 12.342 & $0.001 *$ & 413.542 & 1.811 & $0.120 \mathrm{Ns}$ \\
\hline $\mathrm{Bd}$ & 0.049 & 4.625 & $0.023 *$ & 0.069 & 4.333 & $0.027 *$ \\
\hline $\mathrm{pH}$ & 0.057 & 0.057 & $0.426 \mathrm{Ns}$ & 0.006 & 0.412 & $0.800 \mathrm{Ns}$ \\
\hline $\mathrm{OC}$ & 0.764 & 2.191 & $0.143 \mathrm{Ns}$ & 0.155 & 0.930 & $0.484 \mathrm{Ns}$ \\
\hline $\mathrm{OM}$ & 0.258 & 2.191 & $0.143 \mathrm{Ns}$ & 0.459 & 0.930 & $0.484 \mathrm{Ns}$ \\
\hline TotN & 0.005 & 1.742 & $0.217 \mathrm{Ns}$ & 0.217 & 0.708 & $0.605 \mathrm{Ns}$ \\
\hline AvP & 0.00 & 0.403 & $0.080 \mathrm{Ns}$ & 0.005 & 3.016 & $0.070 \mathrm{Ns}$ \\
\hline CEC & 46.079 & 12.843 & $0.001 *$ & 89.677 & 5.797 & $0.011 *$ \\
\hline $\mathrm{K}+$ & 0.012 & 8.876 & $0.003 *$ & 0.014 & 24.381 & $0.000 *$ \\
\hline $\mathrm{EC}$ & 0.00 & 1.007 & $0.421 \mathrm{Ns}$ & 0.00 & 1.222 & $0.360 \mathrm{Ns}$ \\
\hline
\end{tabular}

*= significant at $\mathrm{P} \leq 0.05 ; \mathrm{NS}=$ Not Significant; $\mathrm{p}=$ probability; $\mathrm{F}=$ Calculated Value; $\mathrm{pH}=$ Potential hydrogen; $\mathrm{EC}=$ Electrical Conductivity; $\mathrm{CEC}=$ Cation Exchange Capacity; TotN = Total Nitrogen; OC = Organic Carbon; $\mathrm{OM}=$ Organic Matter; AvP = Available Phosphorus; $\mathrm{K}+=$ Exchangeable Potassium and $\mathrm{Bd}=$ Bulk density of the soil.

\subsection{Spatial Variability of Selected Soil Chemical Properties in SWC Inter-Structure space Area 3.2.1. Soil Reaction (pH)}

Soil reaction $(\mathrm{pH})$ is a measure of the acidity of the soil based on the concentration of hydrogen ion. The highest $\mathrm{pH}$-values were recorded at 0.00 relative distances or near the deposition which gradually decreased when the relative distance approached to $1.00 \mathrm{~m}$. Whereas, the smallest mean $\mathrm{pH}$-values were recorded at 1.00 relative distances (Table 3). But statistical analysis (Table 2) showed that, in both conservation structures no statically significant different detected among the relative distances at $\mathrm{p}<0.05$ significance level. The result of this study pleasant with the finding of Vancampenhout et al. (2006), in the northern Ethiopia, no significant variation in $\mathrm{pH}$ value between the relative distance were recorded.

The exhibited noticeable decrease in $\mathrm{pH}$-value, explained as the highest mean pH-value of fanya juu and soil bund near the deposition at 0.00 meters relative distance indicates that, the soil is less acidic here as compared to the control (0.50) and upper 1.00-meter relative distances. Most of the time soluble basic cations move from the upper gradient to the lower gradient due to rain splash and concentrate near the deposition and positively contribute for $\mathrm{pH}$ increment. The results of the study consistent with the finding of Olu (1996) who reported that, in the upper slope position the highest amount of soil loss were expected by the cause of erosion and leads to topsoil removal and expose of the sub-surface resulting lower in $\mathrm{pH}$-value.

Probably at the depositional or lower inter-structure spaces zone, most of the organic materials deposited and potential increment of soil pH associated with increase in soil cation. According to Pocknee and Sumner (1997) the decomposition of organic materials which contains basic molecule acts as lime and increase the $\mathrm{pH}$ of the soil. Similarly, organic materials have the capacity to bind acid forming cations and contribute to the reduction of acidic reaction in the soil. 
Table 3: Effect of inter-structural space of fanya juu and soil bund $(\mathrm{m})$ on selected soil chemical properties

\begin{tabular}{|c|c|c|c|c|c|c|c|}
\hline $\begin{array}{l}\text { Relative distance } \\
\text { (m) }\end{array}$ & $\mathrm{Ph}$ & OM \% & TotN \% & $\begin{array}{l}\text { Avp } \\
\mathrm{mg} / \mathrm{kg}\end{array}$ & $\begin{array}{l}\mathrm{K}+ \\
\mathrm{cmol} / \mathrm{kg}\end{array}$ & $\begin{array}{l}\mathrm{CEC} \\
\mathrm{cmol} / \mathrm{kg}\end{array}$ & $\mathrm{EC} \mathrm{S} / \mathrm{cm}$ \\
\hline Lower 0.00 & $6.71 \mathrm{a}$ & $2.69 \mathrm{a}$ & $0.130 \mathrm{a}$ & $1.599 \mathrm{a}$ & $0.277 \mathrm{a}$ & $33.65 a$ & $0.0103 a$ \\
\hline 0.25 & $6.57 \mathrm{a}$ & $3.83 \mathrm{a}$ & $0.173 \mathrm{a}$ & $1.582 \mathrm{a}$ & $0.232 \mathrm{ab}$ & $37.24 \mathrm{ab}$ & $0.0101 \mathrm{a}$ \\
\hline 0.50 (control) & $6.62 \mathrm{a}$ & $3.20 \mathrm{a}$ & $0.227 \mathrm{a}$ & $1.574 \mathrm{a}$ & $0.205 \mathrm{abc}$ & $33.01 \mathrm{a}$ & $0.0077 \mathrm{a}$ \\
\hline 0.75 & $6.56 \mathrm{a}$ & $2.59 \mathrm{a}$ & $0.127 \mathrm{a}$ & $1.578 \mathrm{a}$ & $0.163 b c$ & $27.93 b$ & $0.0079 \mathrm{a}$ \\
\hline Upper 1.00 & $6.34 \mathrm{a}$ & $2.83 \mathrm{a}$ & $0.136 \mathrm{a}$ & $1.577 \mathrm{a}$ & $0.109 \mathrm{c}$ & $28.30 \mathrm{~b}$ & $0.0097 \mathrm{a}$ \\
\hline $\mathrm{SE}( \pm)$ & 0.89 & 0.48 & 0.05 & 0.02 & 0.03 & 1.55 & 0.002 \\
\hline $\mathrm{p}$-value & 0.426 & 0.143 & 0.217 & 0.080 & $0.003 *$ & $0.001 *$ & 0.421 \\
\hline \multicolumn{8}{|c|}{ Plots treated with Soil bund SWC structures } \\
\hline Lower 0.00 & $6.29 \mathrm{a}$ & $1.96 \mathrm{a}$ & $0.100 \mathrm{a}$ & $1.581 \mathrm{a}$ & $0.217 \mathrm{a}$ & $27.69 \mathrm{a}$ & $0.0100 \mathrm{a}$ \\
\hline 0.25 & $6.23 \mathrm{a}$ & $2.42 \mathrm{a}$ & $0.120 \mathrm{a}$ & $1.566 \mathrm{a}$ & $0.135 b$ & $28.31 \mathrm{a}$ & $0.0107 \mathrm{a}$ \\
\hline 0.50 (control) & $6.28 \mathrm{a}$ & $1.63 \mathrm{a}$ & $0.090 \mathrm{a}$ & $1.516 \mathrm{a}$ & $0.098 \mathrm{bc}$ & $19.32 \mathrm{ab}$ & $0.0087 \mathrm{a}$ \\
\hline 0.75 & $6.22 \mathrm{a}$ & $1.38 \mathrm{a}$ & $0.083 \mathrm{a}$ & $1.477 \mathrm{a}$ & $0.054 \mathrm{c}$ & $17.36 b$ & $0.0080 \mathrm{a}$ \\
\hline Upper 1.00 & $6.18 \mathrm{a}$ & $1.87 \mathrm{a}$ & $0.100 \mathrm{a}$ & $1.519 \mathrm{a}$ & $0.055 \mathrm{c}$ & $17.68 \mathrm{~b}$ & $0.0107 \mathrm{a}$ \\
\hline $\mathrm{SE}( \pm)$ & 0.10 & 0.57 & 0.24 & 0.04 & 0.02 & 3.21 & 0.002 \\
\hline p-value & 0.800 & 0.484 & 0.605 & 0.070 & $0.000 *$ & $0.011^{*}$ & 0.360 \\
\hline
\end{tabular}

*statistically significant at $\mathrm{p}<0.05$; columns having the same letters are not statistically significant; $\mathrm{pH}=\mathrm{Potential}$ hydrogen; $\mathrm{EC}=$ Electrical Conductivity $; \mathrm{CEC}=$ Cation Exchange Capacity; Tot $\mathrm{N}=$ Total Nitrogen; $\mathrm{OC}=\mathrm{Organic}$ Carbon; $\mathrm{OM}=$ Organic Matter; AvP = Available Phosphorus; $\mathrm{K}+=$ Exchangeable Potassium and $\mathrm{SE}=\mathrm{Standard}$ Error.

From the Karl person's product movement correlation coefficient (Table 4) each pair of soil properties, soil pH significantly $(\mathrm{p}<0.01)$ and positively correlated with CEC $(\mathrm{r}=0.551)$, total nitrogen $(\mathrm{r}=0.59)$, organic matter $(\mathrm{r}=0.625)$, available phosphorus $(\mathrm{r}=0.610)$, exchangeable potassium $(\mathrm{r}=0.620)$ and clay content $(\mathrm{r}=0.47)$. However, it was negatively correlated with sand $(\mathrm{r}=-0.442)$ at $\mathrm{p}<0.01$ significant level and bulk density $(\mathrm{r}=-$ 0.337 ) at $\mathrm{p}<0.05$ (Table 4). Based on the statistical correlation matrix the study deduces that, soil $\mathrm{pH}$ and organic matter $(\mathrm{r}=0.625)$ positively and highly correlated in relative to other soil properties.

\subsubsection{Soil Organic Carbon/Organic Matter}

There was no significant different among the relative distances between inter-structural space in both conservation structures at $p<0.05$ significance level in the case soil organic carbon content (Table 2 and Table 3 ). Based on rating of Landon (1991), the mean values OM in the range of low (Table 5). According to Vancampenhout et al (2006) soil organic carbon values were mostly lower in the Ethiopian highlands as a case of frequent grazing and the absence of fallowing period.

In this study in both SWC structures, at 0.25 -meter relative distance, the organic carbon or organic matter $(\mathrm{OC} / \mathrm{OM})$ values was maximum as compared to the other relative distances, and the lowest value at 0.75 -meters in fanya juu and soil bund respectively (Table 3). The results of the study were consistent with the finding of Worku et al. (2012) study on the effects of 'fanya juu' soil conservation structure on selected soil physical and chemical properties, the case of Goromit watershed, western Ethiopia, where they reported, the highest soil organic carbon contents were found in the lower gradient as compared to the upper. Similarly, Tadele et al. (2013) reported that, in Anjeni watershed, central highlands of Ethiopia, the mean organic carbon content at bottom gradient were highest next to the foot of the structures. Around the shoulder zone of the SWC structures the lowest OM contents was recorded than the rest. Bottom and foot gradients are relatively flatter in which soil erosion is expected to be negligible as compared to the shoulder and upper gradients, leading to more accumulation of OM in the field.

The process of erosion and transposition of organic materials from the top to the down between the conservation inter-structure area of the terraced plots might be another case for differences in organic matter variation. During rainy season runoff flow with carrying some soil nutrient and other plant materials (organic materials) which combination of large plant fragment and debris towards the depositional zone. Through time the runoff hydraulic force declining and larger plant residues left before reaching to the end point of deposition at 0.00 -meter relative distance.

Mitiku et al. (2006) described that, when runoff concentration and velocity diminish, the eroded material can be deposited in concentrated accumulations. The reverse process was achieved at the erosional zone, near to 0.75 $\mathrm{m}$ relative distances; at this point near the top, or far a certain distance from the buffer area; runoff velocity and erosivity power increased. Because of the position of higher slope and barren area as compared to other positions. Instantly, erosional zones are less available in soil materials and highly weathered as compared to the lower zone. According to Kirkels et al. (2014) investigation, "the light weighted nature of organic materials makes them easy to be transported to the depositional zones or lower zone and leads to creating greater exposure on erosional zones (less stock in soil organic carbon matter content). Vancampenhout et al. (2006), also indicated that, at the zone where runoff hydraulics abruptly changed and net deposition starts and the coarsest fragments (small crop residue 
fragments in this case) were concentrated. In the test plots, this change of slope occurred near the $0.25 \mathrm{~meter}$ position where most organic carbon was loaded, which indicates a strong influence of organic carbon and organic matter transport as water erodes crop residues. The revers process was observed at the top of the terrace; most of the organic carbon was lost in relative distance 0.75 , where the local slope gradient and the runoff erosivity dramatically increases. Likewise, Saiz et al. (2016) also reported that, conservation structures promote siltation and the accumulation of plant debris at lower locations.

Comparison matrix (Table 4$)$ revealed that, the soil organic carbon positively $(\mathrm{p}<0.01)$ and significantly correlated with $\mathrm{pH}\left(\mathrm{r}=0.652^{* *}\right)$ and clay $\left(\mathrm{r}=0.433^{*}\right)$ at $(\mathrm{p}<0.05)$ positively correlated. On the other hand, it correlated negatively and significantly $(\mathrm{p}<0.05)$ with sand content $\left(\mathrm{r}=-0.348^{*}\right)$ with no significant relationship with bulk density $(r=-0.139)$. As compared to other soil properties, favorably the organic matter content of the sampled soil strongly and positively $(\mathrm{r}=0.679 * *)$ related with cation exchange capacity at $(\mathrm{p}<0.05)$ significance level. At the same instance negatively $(\mathrm{p}<0.01)$ significant correlation of OM with sand content $(\mathrm{r}=-0.450)$ was observed.

\subsubsection{Total nitrogen (Tot N\%)}

On the fanya juu conservation structures, the highest and the lowest mean values of total nitrogen $(0.227 \%)$ at 0.50 -meter relative distance and the $(0.127 \%)$ at 0.75 meter were recorded respectively. On the other hand, between inter-structural space of soil bund, the highest and the lowest $(0.120 \%, 0.083 \%)$ were detected at $0.25 \mathrm{~m}$ and 0.75 $\mathrm{m}$ respectively (Table 3 ). But the differences were not significant. The possible explanation for the variation might be (erosion and deposition process during heavy rainfall); lower zones are depositional zones and upper gradient areas is soil loss zones, nitrogen is mostly readily lost because of its high solubility in the nitrate form in the soil. The finding of the study agreed with that of Tadele et al. (2011), who pointed out that, on terraced land soils are actively eroded from the soil loss zone and deposited to the soil accumulation zone creating spatial variability in terms of moisture and nutrient availability within the inter-structure area of terraced plots. However, the variations were not significant in both SWC structures at 95\% confidence level (Table 2). The finding of this study is contrary that of Worku et al. (2012), who reported significant variation in the total nitrogen content with respected to slope gradient. It also contradicts with that of Abay et al. (2016), significantly higher total nitrogen on the lower gradient than that of the higher gradient.

Based on the rating, the mean value of total nitrogen (Tot N) falls the range of weak $(<0.2)($ Table 5) following (Landon, 1991). The reasons might be, farmers mostly use plant residues and animal dungs for fire wood consumption instead of used as an organic input. There is also the lack of biological conservation practices like legume trees and shrubs intervention in the conservation practices. Similar results were reported by Worku et al. (2012) who indicated that rapid mineralization of existing low organic matter content and the absence of incorporation of leguminous plants which have the capacity to fix nitrogen from the air through the nodules of their roots in the land management practices leads to lowering of nitrogen availability in the soil.

From the correlation matrix (Table 4$)$ total nitrogen correlated positively and significantly $(\mathrm{p}<0.01)$ with organic matter $(r=0.623)$, available phosphorus $(r=0.434)$ and clay content $(r=0.343)$. However, negatively correlated with bulk density $(r=-0.201)$ and $(r=-0.304)$ sand and the correlation is not significant in both case at $(\mathrm{p}<0.01$ and 0.05 . The result is in line with that of Mwango et al. (2015) who reported that total nitrogen was significantly correlated with $\mathrm{OC}$ and phosphorus $(\mathrm{p}<.001)$.

\subsubsection{Available phosphorus (AvP mg/kg) and exchangeable potassium $(\mathrm{K}+\mathrm{cmol} / \mathrm{kg})$}

Pareason product movement correlation (Table 4) revealed that, available phosphorus (AvP) and exchangeable potassium $(\mathrm{K}+)$ of the sampled soil between the successive structures were positively and significantly $(\mathrm{p}<0.01)$ correlated with $\mathrm{pH}\left(\mathrm{r}=0.610^{* *}, 0.620^{* *}\right)$, organic matter content $\left(\mathrm{r}=0.648^{* *}, 0.577^{* *}\right)$ cation exchange capacity $\left(\mathrm{r}=0.652^{* *}, 0.772^{* *}\right)$ and clay content $\left(\mathrm{r}=0.487^{* *}, 0.696^{* *}\right)$. Moreover, significant $(\mathrm{p}<0.01)$ negative correlation with sand content $\left(\mathrm{r}=-0.450^{* *},-0.634 * *\right)$ were observed respectively. Exchangeable potassium is significantly at $(\mathrm{p}<0.01)$ and negatively $(\mathrm{r}=-0.431)$ correlated with bulk density. The results of this study is consistent with the finding of Mwango et al. (2015) who reported that, a significant correlation between phosphorus and soil $\mathrm{pH}$ was observed.

According to Olsen (1965) rating, available phosphorus ranges from of (0 to $3 \mathrm{mg} / \mathrm{kg}$ ) in the study area is very low. While exchangeable potassium was rated as weak, based on the rating of Landon (1991) with less than $0.2 \mathrm{cmol} / \mathrm{kg}$ (Table 5). The result of the study deduces that, the value of available phosphorus (AvP) was not significantly affected by relative distance in both SWC structures at $\mathrm{p}<0.05$ (Table 2). Whereas, the concentration of exchangeable potassium was significantly influenced in both SWC inter-structures plot area. Consequently, the maximum average $(0.277$ and $0.217 \mathrm{cmol} / \mathrm{kg})$ at 0.00 meter and the smallest average $(0.109$ and $0.054 \mathrm{cmol} / \mathrm{kg})$ of exchangeable potassium at 1.00 and 0.75 -meter relative distances in fanya juu and soil bund between the consecutive structures were recorded respectively.

The largest mean available phosphorus $(1.599$ and $1.581 \mathrm{mg} / \mathrm{kg})$ at $0.00 \mathrm{~m}$ and minimum average $(1.574$ and $1.477)$ at 0.50 and 0.75 -meter relative distance were detected respectively in the successive SWC structures of fanya juu and soil bund respectively (Table 3). Changing relative distance from upper (1.00 meter) to lower 
gradient $(0.00$ meter) relative distance, the concentration of available phosphorus and exchangeable potassium, respectively increased by $1.40 \%, 4.10 \%$ and $60.65 \%, 74.65 \%$ in fanya juu and soil bund SWC structures consecutively. Significantly higher mean value of exchangeable potassium $(\mathrm{K}+)$ at 0.00 -meter relative distance than others was observed. Exchangeable $(\mathrm{K}+)$ and available phosphorus (AvP) generally increased down slope in related to relative distance. A similar trend reported by Vancampenhout et al. (2006), in the northern Ethiopian highlands with high fertility in the accumulation zone (relative distance 0.00 meter) and a gradual lower fertility towards the erosion zone relative distance $(1.00 \mathrm{~m})$.

The could be runoff causes erosion and leads to potential redistribution of soil and organic materials within and between the successive inter-structure terrace area. Mitiku et al. (2006) revealed that, diffuse accumulations of eroded material may occur, which partly refill the pre-rills. The situation represents, the erosion on a terrace between two successive SWC structures; such as soil bund or fanya juu. On the other way in the eroded part, rain splash, sheet flows, may occur. On the deposition part, fine material accumulations and plant debris accumulations are found above the SWC structures. The movement of available phosphorus (AvP) from the zone of erosion towards the depositional or accumulation zone slightly increasing in concentration or more consistent relative to exchangeable potassium $(\mathrm{K}+)$ Concentration.

The possible explanation probably, the relative mobility and soil adhering capacity of the nutrient itself. The results of this study are consistent with the investigation of Santillano et al. (2012), the patterns of lateral and by slope movements regardless of fertilizer potassium $(\mathrm{K}+)$ had more lateral mobility than phosphorus. Another finding, reported by Esser et al. (2002); Dercon et al. (2003); Vancampenhout et al. (2006); Mwango et al. (2015) the higher phosphorus contents in the lower gradient that are explained as the capacity of phosphorus to strongly adhere to the soil particles case the available form of phosphorus (phosphate) is negatively charged thereby always adheres to on active sites on the surfaces of soil particles; attributes to transport down slope by tillage and water erosion.

\subsubsection{Cation Exchange Capacity of the Soil $(\mathrm{CEC} \mathrm{cmol}(+) / \mathrm{kg})$}

The correlation matrix (Table 4) revealed that, cation exchange capacity (CEC) of the soil positively and significantly $(\mathrm{p}<0.01)$ strongly correlated with clay content $(\mathrm{r}=0.712)$ and organic matter $(\mathrm{r}=0.679)$. According to FAO (2000), the soil CEC is a measure of the quantity of negative charges present in the mineral and organic surfaces of the soil and represents the quantity of cations that can be held on these surfaces and directly related to the amount and type of clay as well as the organic matter content of the soil. Soils which contain higher organic matter have a high CEC value (Mulugeta and Stahr, 2010). However, the cation exchange capacity of the sampled soils negatively and significantly correlated $(\mathrm{p}<0.01, \mathrm{r}=-0.667)$ with sand, $(\mathrm{r}=-0.519)$ and $(\mathrm{p}<0.05, \mathrm{r}=-0.402)$ bulk density respectively. The output of this study is in agreement with the finding of Abay et al. (2016) who indicated that, improving soil organic matter content can significantly increase soil CEC, and high clay fraction along with soil organic matter may also attribute to high rate of soil CEC.

The CEC values significantly varied between the relative distance at $\mathrm{p}<0.05$ significance level (Table 2 ). Tukey (HSD test) indicates that, there is a significant different between 0.00, 0.25, and 0.75, 1.00 meters relative distances, but no significant differences were observed between 0.00 and $0.50 \mathrm{~m}$ and 0.75 and 1.00 meters. Significantly higher mean value $(37.24 \mathrm{cmol} / \mathrm{kg})$ was recorded under 0.25 -meter relative distance while the lowest $(27.93 \mathrm{cmol} / \mathrm{kg}$ ) was recorded under 0.75 meter in the fanya juu SWC structures (Table 3). Whereas, in the case of soil bund significant variation between 0.00 and $0.5,0.75$ - and 1.00-meters relative distance and no significant different between 0.75 and 1.00 meters (Table 3 ) at $p<0.05$ significance level. Near the lower relative distance ( 0.25 meter), significantly higher mean values were achieved. Similarly, Tadele et al. (2013), reported significant different between different gradient for the mean value of cation exchange capacity (CEC) was observed at $p \leq$ 0.05 .

The highest mean cation exchange capacity value at 0.25 -meter relative distance or near the lower gradient, might be due to the transport and deposition process of the running water during the rainfall event between the inter-structure conservation plot. At a time, some soluble cations might have leached and clay minerals transported to the next lowest gradient combined with other plant residues and organic debris. After going on, plant residues and large organic materials left before reaching to the zones of deposition ( 0.00 meter $)$ relative distance. In spite of this, the accumulation of organic materials performed near to 0.25 -meter relative distance than smaller particles. Through time those debris and large organic materials decomposed and changed to inorganic form and case for the addition of the cation exchange capacity of the site.

In contrast the lowest CEC values were observed at the 0.75 -meter relative distance zone. Due to erosion intensity; the running water start to flow at the top of the structures and goes to down at a certain distance near to 0.75-meter relative distances or at the back site of the structure. Simultaneously, the kinetic energy of the falling water starts to increase slowly and maximized; at the moment erosion was powerful as compared to other relative distances. According to Mahmoodabadi and Sajjadi (2016), mostly in the upper gradient, soil particles and basic elements of soil nutrients were washed away as a consequence of higher flow velocity and power of runoff. Also, Vancampenhout et al. (2006) reported that, the location where runoff hydraulics suddenly change and net 
deposition starts, therefore moves upslope with time even over short periods of terrace formation. Large plant residues and coarsest (organic debris) fragments were deposited and change of slope gradient is located around the 0.25 -meter position where most organic matter and some dissolved menials were found. The opposite effect is observed at the top of the terrace; more organic matter is lost in relative distance 0.75 meter, where the local slope gradient and runoff erosivity abruptly increases and poor soil condition appeared.

\subsubsection{Electrical conductivity of Soil (EC S/m)}

The possible highest and lowest mean value of EC $0.0103 \mathrm{~S} / \mathrm{m}$ and $0.0077 \mathrm{~S} / \mathrm{m}$ in fanya juu and $0.0107 \mathrm{~S} / \mathrm{m}$ and $0.008 \mathrm{~S} / \mathrm{m}$ in soil bund were recorded respectively (Table 3). However, there is no significant different between the relative distance at $\mathrm{p}<0.05$ significance level (Table 2 ). Regardless of the significant differences, the electrical conductivity value of the sampled soil, highest at 0.00 -meter relative distances as compared to the control or the central relative distance in fanya juu and at 0.25 meter and at 1.00 in soil bund (Table 3 ). The tangible increment of EC value at 0.00 -meter relative distances might be due to the movement of salt forming cations down to the depositional zone. Instantly some debris and plant residues as well as clay minerals transported and left from erosion. At the lower slope positions, water has a relatively longer residence time and as a result, soluble materials precipitate down (Olarieta et al., 2008). These plant materials contribute to the potential availability of positively charged ions and fine particles leads to increase charge exchange sites. Additionally, positive correlation between soil electrical conductivity and cation exchange capacity of the soil $(r=0.117)$ were observed, but the correlation is not significant either $\mathrm{p}<0.01$ or $\mathrm{p}<0.05$ significance level (Table 4). The availability of cation exchange capacity and clay percentages were positively influenced the electrical conductivity of the soil (Shainberg et al., 1980).

Table 4: Pearson's correlation matrix for selected soil physicochemical properties

\begin{tabular}{|c|c|c|c|c|c|c|c|c|c|c|c|c|}
\hline & R-D & $\mathrm{pH}$ & $\mathrm{EC}$ & CEC & TotN & OM & $\mathrm{AvP}$ & $\mathrm{K}+$ & $\mathrm{Bd}$ & Clay & Silt & $\mathrm{S}$ \\
\hline R-D & 1 & & & & & & & & & & & \\
\hline $\mathrm{Ph}$ & -.292 & 1 & & & & & & & & & & \\
\hline $\mathrm{EC}$ & -.180 & $-.486 * *$ & 1 & & & & & & & & & \\
\hline CEC & $-.514 * *$ & $.551^{* *}$ & .177 & 1 & & & & & & & & \\
\hline TotN & -.099 & $.590 * *$ & -.272 & $.532 * *$ & 1 & & & & & & & \\
\hline $\mathrm{OM}$ & -.173 & $.652 * *$ & -.174 & $.679 * *$ & $.623 * *$ & 1 & & & & & & \\
\hline AvP & $-.406 * *$ & $.610^{* *}$ & -.082 & $.652^{* *}$ & $.434 * *$ & $.648^{* *}$ & 1 & & & & & \\
\hline $\mathrm{K}+$ & $-.741 * *$ & $.620 * *$ & .010 & $.772 * *$ & $.420 *$ & $.577 * *$ & $.619 * *$ & 1 & & & & \\
\hline $\mathrm{Bd}$ & $.627 * *$ & $-.337 *$ & .65 & $-.402 *$ & -.201 & -.139 & .312 & $-.431 * *$ & 1 & & & \\
\hline Clay & $-.510 * *$ & $.47 * *$ & -.015 & $.0712 * *$ & $.343^{*}$ & $.343 *$ & $.487 * *$ & $.690 * *$ & $-.620 * *$ & 1 & & \\
\hline Silt & -.154 & .94 & -.281 & .135 & .017 & .139 & .075 & .083 & $-.607 * *$ & .88 & 1 & \\
\hline Sand & $.154 * *$ & $-.442 * *$ & .114 & $-.667 * *$ & -.304 & $-.348^{*}$ & $-.450 * *$ & $-.634 * *$ & $.755 * *$ & $-.936 * *$ & $-.521 * *$ & 1 \\
\hline
\end{tabular}

** Correlation is significant at 0.01 (one-tailed) and * correlation is significant at 0.05 (one-tailed) where R_D: relative distance; S- sand content; EC-electrical conductivity; CEC-cation exchange capacity; TotN-total nitrogen; OM-organic matter; AvP-available phosphorus; $\mathrm{K}+$-exchangeable potassium $(\mathrm{K}+)$; Bd-bulk density of the soil; $\mathrm{pH}$ potential Hydrogen

Table 5: Rating of some soil chemical properties (Landon, 1991)

\begin{tabular}{llllll}
\hline Parameters & Very weak & Weak & Medium & High & Very high \\
\hline CEC $(\mathrm{cmol} / \mathrm{kg})$ & $<5$ & $4-15$ & $15-25$ & $25-40$ & $>40$ \\
Total nitrogen $(\%)$ & & $<0.2$ & $0.2-0.5$ & $>0.5$ & \\
Available phosphorus $(\mathrm{mg} / \mathrm{kg})$ Olsen, $(1965)$ & $0-3$ very low & $3-8$ low & $8-14$ & $14-20$ & $>20$ \\
Exchangeable potassium (cmol/kg) & & $<0.2$ & $0.2-0.6$ & $>0.6$ & \\
Organic carbon $(\%)$ & & $<4$ & $4-10$ & $>10$ & \\
Organic matter $(\%)$ & $<2$ very low & $2-4$ low & $4-10$ & $10-20$ & $>20$ \\
\hline
\end{tabular}

\section{CONCLUSION}

Land degradation is one of the most important environmental problems that hinders the productive capacity of farm plots and thereby negatively affects community livelihoods in Ethiopia. To overcome the problem and improve the productivity of degraded environment, the government widely initiated soil and water conservation (SWC) practices and extensively introduced in the past ten years. In this regard, I tried to evaluate the soil property variation within the inter-structure terrace area of fanya juu and soil bund conservation practices in Habru district specific watershed of Kutaye catchment.

The soil and water conservation (SWC) structures that I evaluated, influenced soil properties by changing soil loss and accumulation process (erosion and deposition). In most case, except bulk density and sand content all soil fertility indicators were concentrated around 0.00 and 0.25 -meters relative distances and goes decreased as the relative distance increased from the lower embankment. Nevertheless, the variation was significant only in cation exchange capacity (CEC), exchangeable potassium $(\mathrm{K}+)$ and bulk density in both conservation structures. Whereas, the percentage of clay and sand were only significant between relative distance of plots which treated with fanya juu. From the results of soil analysis concluded that, soil fertility indicators were partially and significantly 
influenced by inter structure space of conservation structures (fanya juu and soil bund) at $\mathrm{p}<0.05$.

Site specific soil fertility management might be the best alternatives to overcome some spatial variability problem in soil properties between inter-structure conservation areas. Additionally, tillage operations appropriately following the contour; incorporation of some desirable plant species and bund stabilization will be needed.

\section{ACKNOWLEDGEMENT}

The authors would like to express their sincere gratitude to the staff of Sirinka regional agricultural research institute (SRARI) for assistance, cooperation and material support during field data collection and soil laboratory analysis. The financial support provided by Jimma University which is lead by Ethiopian ministry of finance and economic development is also greatly acknowledged.

\section{REFERENCES}

Abay, C., Abdu, A. and Tefera, M., 2016. Effects of Graded Stone Bunds on Selected Soil Properties in the Central Highlands of Ethiopia. International Journal of Natural Resource Ecology and Management, 1(2): 42-50.

Alemayehu, M., Yohannes, F. and Dubale, P., 2006. Effect of Indigenous Stone Bunding (Kab) on Crop Yield at Mesobit-Gedeba, North Shoa, Ethiopia. Land Degradation Develop, 17: 45-54.

Amsalu, A. and De Graaff, J., 2007. Determinants of Adoption and Continued Use of Stone Terraces for Soil and Water Conservation in an Ethiopian Highland Watershed. Ecological Economics, 61: 294-302.

Assemu, T. and Shigdaf, M., 2014. The Effect of Land Degradation on Farm Size Dynamics and Crop-Livestock Farming System in Ethiopia: O.J.S.S, 4: 1-5.

Badege, B., 2001. Deforestation and Land Degradation in Ethiopian Highlands, Strategy for Physical Recovery, Northwest African Studies, Michigan State University. Ee-J.R.I. F. 1(1): 5-18.

Bashour, I.I. and Sayegh, A.H., 2007. Methods of Analysis for Soils of Arid and Semi-Arid Regions. FAO.

Berhanu, G. and Swinton, S.M., 2003. Investment in Soil Conservation in Northern Ethiopia: Land Tenure Security and Public Programs. Agricultural Economics, 29: 69-84.

Bewket, W., 2001. The Need for a Participatory Approach to Soil and Water Conservation (SWC) in the Ethiopian Highlands: A Case Study in Chemoga Watershed, East Gojjam. Eastern Africa Social Science Research Review, 17(2): 43-68.

Bewket, W. and Sterk, G, 2002. Farmers' Participation in Soil and Water Conservation activities in the Chemoga Watershed, Blue Nile Basin, Ethiopia. Land degradation and development, 13: 189-200.

Bewket, W., 2007. Soil and Water Conservation Intervention with Conventional Technologies in Northwestern Highlands of Ethiopia: Acceptance and Adoption by Farmers. Land Use Policy, 24(2): 404-416.

Birhanu, A.M. and Assefa, A.Y., 2017. Spatial Variability of Selected Soil Properties in Relation to Land Use and Slope Position in Gelana Sub-Watershed, Northern Highlands of Ethiopia. Physical Geography, 20: 1-16.

Black, C. A., 1965. Methods of soil analysis. Madison, WI: American Society of Agronomy, Agronomy No. 9, Part 2.

Chapman, H. D., 1965. Cation Exchange Capacity. in C. A. Black (Ed.) Methods of Soil Analysis Chemical and Microbiological Properties, Madison, WI: American Society of Agronomy, 9: 891-901.

CSA, 2007, Statistical Reports of the Census for Amhara Region, Population Size and Characteristics; Part Ii.

Dercon, G., Deckers, J., Govers, G., Poesenc, J., Sáncheza, H., Vanegasa, R., Ram, M. and Loaizaa, G., 2003. Spatial Variability in Soil Properties on Slow-Forming Terraces in the Andes Region of Ecuador. Soil and Tillage Research, 72(1): 31-41.

Dessalegn, C. D., Christian D.G., Assefa D.Z, Tigist Y.T., Menelik, G., Solomon, A., Fasikaw A. Z., Essayas K. A., Seifu, A. T. and Tammo S. S., 2015. Impact of Conservation Practices on Runoff and Soil Loss in the Sub-Humid Ethiopian Highlands: the Debre Mawi Watershed. J. Hydrol. Hydromech, 63 (3): 210-219.

Esser, K., Vagen, T.G. and Haile, M., 2002. Soil Conservation in Tigray (No. 5, P. 21). Ethiopia Noragric Report.

FAO (Food and Agriculture Organization of the United Nations) (1986). Ethiopian, Highland Reclamation Study. Final Report, Vol, 1. FAO, Rome, 334 Pp.

FAO (Food and Agriculture Organization of the United Nations) (2000). Manual on Integrated Soil Management and Conservation Practices, International Institute of Tropical Agriculture (IITA) Ibadan, Nigeria.

FSC and DPO, 2011. The Development Study on the Improvement of Livelihood through Integrated Watershed Management the Government of Amhara National Regional State the Federal Democratic Republic of Ethiopia Final Report. Pp. 17-21.

Gupta, P.K., 2004. Soil, Plant, Water and Fertilizer Analysis. Shyam Printing Press, Agro-Bios, India. 438p.

Hamidreza, S., Kiani, M. and Asadi, H., 2017. Variability of particle size distributions of upward/ downward splashed materials in different rainfall intensities and slopes. Geoderma, 290: 100-106.

Herweg, K. and Ludi, E., 1999. The Performance of Selected Soil and Water Conservation Measures Case Studies from Ethiopia and Eritrea. Catena, 36(1): 99-114.

HWRDAOR, 2012. Habru Woreda Rural Development and Agriculture Office's Report. 
Jackson, M. L., 1958. Soil chemical analysis. Engle wood cliffs, NJ: Prentice Hall, pp. 125.

Justin, M., L. John, K., K. Fred, S. and O. Peter, k., 2012. Comparison of Soil Phosphorous extraction by Olsen and Double Acid Methods in Acid soils of Western Kenya. East African Journal of Pure and Applied Science, 2(1): $1-5$.

Kebede, W., Awdenedest, M. and Fentaw, Y., 2011. Effects of Level Soil Bunds and Stone Bunds on Soil Properties and its Implications for Crop Production: The Case of Bokole Watershed, Dawuro Zone, Southern Ethiopia. Agricultural Sciences, 2(03): 357.

Kessler, A., Amsalu, A., Bondar, F., Posthumus, H. and Tenge, A., 2008. Factors Influencing Adoption and Continued Use of Long-Term Soil and Water Conservation Measures in five Developing Countries. Applied Geography, 28: 271-280.

Kettler, T.A., Doran, J.W. and Gilbert, T.L., 2001. Simplified Method for Soil Particle-Size Determination to Accompany Soil-Quality Analyses. Soil Science Society of America Journal, 65(3): 849-852.

Kirkels, F.M.S.A., Cammeraat, L.H. and Kuhn, N.J., 2014. Geomorphology the Fate of Soil Organic Carbon Upon Erosion, Transport and Deposition in Agricultural Landscapes a Review of Different Concepts. Geomorphology, 226: 94-105.

Lakew, D., Menal, K., Benin, S. and Pender, J., 2006. Land Degradation and Strategies for Sustainable Development in Amhara Region, Ethiopian Highlands. Pp. 9-15. Socio-Economics and Policy Research Working Paper 32.

Landon, J.R., 1991. Booker Tropical Soil Manual. A Handbook for Soil Survey and Agricultural Land Evaluation in the Tropics and Subtropics. JR Lndon (Ed.) Longman Scientific and Technical Co-Published in the United States with John Wiley and Sons. Inc., New York.

Lindstrom. M.J. And Li. Y., 2001 "Evaluating Soil Quality Soil Redistribution Relationship on Terraces and Steep Hill Slope”. Soil Science Society of America Journal, 65: 1500-1508.

Mahmoodabadi, M. and Sajjadi, S.A., 2016. Geomorphology Effects of Rain Intensity, Slope Gradient and Particle Size Distribution on the Relative Contributions of Splash and Wash Loads to Rain-Induced Erosion. Geomorphology, 253: 159-167.

Million, A., 2003. Characterization of Indigenous Stone Bunding (Kab) and its Effect on Crop Yield and Soil Productivity at Mesobit-Gedba, North Showa Zone of Amhara Region, M.Sc. Thesis, Alemaya University, Alemaya, Ethiopia.

Mitiku, H., Herweg, K. and Stillhardt, B., 2006. Sustainable Land Management a New Approach to Soil and Water Conservation in Ethiopia. Mekelle, Ethiopia: Land Resources Management and Environmental Protection Department, Mekelle University; Bern, Switzerland: Centre for Development and Environment (CDE), University of Bern, and Swiss National Centre of Competence in Research (NCCR) North-South. 269 pp.

MOFED, 2010. Growth and Transformation Plan of Ethiopia (GTP), 2010/2011-2014/15 of the Federal Democratic Republic of Ethiopia (FDRE).

MOFED, 2013. Growth and Transformation Plan of Ethiopia (GTP), annual Progress Report for F.Y. 2011/12 of the Federal Democratic Republic of Ethiopia (EDRE).

Mulugeta, D. and Stahr, K., 2010. Assessment of Integrated Soil and Water Conservation Measures on Key Soil Properties in South Gondar, North-Western Highlands of Ethiopia. Journal of Soil Science and Environmental Management, 1(7): 164-176

Mwango, S.B., Msanya, B. M., Mtakwa, P. W., Kimaro, D. N., Deckers, J., Poesen, Meliyo, J. J. L. and Dondeyne, S., 2015. Soil Fertility and Crop Yield Variability under Major Soil and Water Conservation Technologies in the Usambara Mountains Tanzania. Journal of Scientific Research and Reports, 5(1): 32-46.

NTNU, 2002. Svein Ege, "North Wälo 1:100,000. Topographic and Administrative Map of North Wälo Zone, Amhara Region, Ethiopia".

Olarieta J.R., Rodrıguez-Valle F.L. and Tello E., 2008. Preserving and Destroying Soils, Transforming Landscapes Soils and Land-Use Changes in The Valley's County (Catalonia, Spain). Land Use Policy, 25(4): 474-484.

Olsen, S. R., 1965. Test of an Ascorbic Acid Method for Determining Phosphorus in Water and Nahc03 Extracts from the Soil Science. Society of America Proceedings, 29: 677-678.

Olu Obi, 1996. Long Term Effect of Continuous Cultivation of Tropical Ultisol in South Western Nigeria. P. $207-$ 215.

Pocknee, S. and Sumner, M.E., 1997. Cation and Nitrogen Contents of Organic Matter DetermineiIts Soil Liming Potential. Soil Science Society of America Journal, 61(1): 86-92.

Saiz, G., Wandera, F.M., Pelster, D.E., Ngetich, W., John R., Okalebo, W.J.R., Rufino, M.C, and Butterbach-Bahl, K., 2016. Geoderma Long-term Assessment of Soil and Water Conservation Measures (Fanya-juu terraces) on Soil Organic matter in South Eastern Kenya. Geoderma, 274: 1-9.

Santillano, J., Goad, C. and Rueda-puente, E.O., 2012. Spatial and Temporal Variability of Soil Fertility. Journal of Plant Nutrition, 35: 2055-2066.

SERA-IEG, 1995. Soil Testing and Plant Analysis, Interpreting Soil Organic Matter Tests, Southern Region of the 


\section{U.S.}

Shainberg, I., Rhoades, J.D. and Prather, R.J., 1980. Effect of Exchangeable Sodium Percentage, Cation Exchange Capacity, and Soil Solution Concentration on Soil Electrical Conductivity. Soil Science Society of America Journal, 44(3): 469-473.

Shiene, D.S., 2012. Effectiveness of Soil and Water Conservation Measures for Land Restoration in The Wello area, Northern Ethiopian Highlands. Ecological Development Series No, 89, 2012.

Tadele, A., Yihenew, G.S., Mitiku, H. and Yamoh, C., 2011. Effect of Soil and Water Conservation Measures on Selected Soil Physical and Chemical Properties and Barley (Hordeum Spp.) Yield. Journal of Environmental Science and Engineering, 5: 1483-1495.

Tadele, A., Aemro, T., Yihenew, G.S., Birru, Y., Bettina, W. and Hurni, H., 2013. Soil Properties and Crop Yields along the Terraces and Topo-sequence of Anjeni Watershed, Central Highlands of Ethiopia. Journal of Agricultural Science, 5(2): 134.

Tilahun, A., Takele, B. and Edrias, G., 2001. Reversing Degradation of Arable Lands in Southern Ethiopia1. Managing African Soils, 23: 1-15.

Vancampenhout, K., Nyssen, J., Desta, G., Deckers, J., Poesen, J., Mitiku, H. and Moeyersons, J., 2006. Stone Bunds for Soil Conservation in the Northern Ethiopian Highlands: Impacts on Soil Fertility and Crop Yield. Soil and Tillage Research, 90(1-2): 1-15.

Worku, H., Awdenegest, M. and Fentaw, Y., 2012. The Effects of "Fanya juu" Soil Conservation Structure on Selected Soil Physical and Chemical Properties: The Case of Goromti Watershed, Western Ethiopia. Resources and Environment, 2(4): 132-140.

Zingore, S., Mutegi, J., Agesa, B., Tamene, L. and Kihara, J., 2015. Soil Degradation in Sub-Saharan Africa and Crop Production Options for Soil Rehabilitation. Better Crops Plant Food, 99(1): 24-26.

\section{Bibliography}

The $1^{\text {st }}$ author, Muluneh Bogale Abate, was born on $23^{\text {rd }}$ of October 1992 in Gubara Habru district North Wollo zone Amhara regional state of Ethiopia. He attended his primary at Gubara primary school from 2000-2006, secondary education at Sirika general secondary school from 2007-2010 and preparatory education at Woldiya preparatory school from 2011-2012. After he has successfully passed the Ethiopian school leaving certificate examination, he joined Gondar University in 2012 and graduated with bachelor of science degree in natural resource management in July 2015. In September 2015, he joined Jimma University to pursue graduate study leading to Master of science degree in natural resource management (watershed management) and he graduated in January 2018. At the present moment the author works as a lecturer at Debark University in Ethiopia. 